\title{
Fetal 2-D ultrasonography in maternal Graves' disease
}

Małgorzata Gietka-Czernel,

Corresponding Affiliation: Aff1

Email: malgietka@vp.pl

\begin{tabular}{|c|c|c|}
\hline \multicolumn{3}{|r|}{ ArticleInfo } \\
\hline ArticleID & $\|:\|$ & 197 \\
\hline ArticleDOI & $: \|$ & 10.1186/1756-6614-8-S1-A9 \\
\hline ArticleCitationID & $: \mid$ & A9 \\
\hline ArticleSequenceNumber & $: \|$ & 9 \\
\hline ArticleCategory & $: \mid$ & Meeting abstract \\
\hline ArticleFirstPage & $\|:\|$ & 1 \\
\hline ArticleLastPage & $: \mid$ & 3 \\
\hline ArticleHistory & $: \|$ & $\begin{array}{ll}\text { RegistrationDate } & : 2015-6-22 \\
\text { OnlineDate } & : 2015-6-22\end{array}$ \\
\hline ArticleCopyright & $\|$ : & $\begin{array}{l}\text { Gietka-Czernel; licensee BioMed Central Ltd.2015 } \\
\text { This article is published under license to BioMed Central } \\
\text { Ltd. This is an Open Access article distributed under the } \\
\text { terms of the Creative Commons Attribution License } \\
\text { (http://creativecommons.org/licenses/by/4.0), which permits } \\
\text { unrestricted use, distribution, and reproduction in any } \\
\text { medium, provided the original work is properly cited. The } \\
\text { Creative Commons Public Domain Dedication waiver } \\
\text { (http://creativecommons.org/publicdomain/zero/1.0/) applies } \\
\text { to the data made available in this article, unless otherwise } \\
\text { stated. }\end{array}$ \\
\hline
\end{tabular}

Aff1

Endocrinology Department CMKP, ul. Marymoncka 99, 01-813 Warszawa, Poland

Spring School of Thyroidology organized by the Polish Thyroid Association 2014: abstracts of invited lectures

Spring School of Thyroidology organized by the Polish Thyroid Association 2014

Miedzyzdroje, Poland

23-24 May 2014

Publication of this supplement was funded by the Polish Thyroid Association. The Supplement Editors declare that they have no competing interests.

Meeting abstracts

Andrzej Lewinski

Mariusz Stasiolek 
Graves' disease complicates about $0.1-1.0 \%$ of all pregnancies $[\underline{1}, \underline{2}]$. Despite its rare occurrence in pregnant women, Graves' disease constitutes a great therapeutic challenge. Maternal thyroid stimulating antibodies (TSAbs) cross the placenta and can overstimulate the fetal thyroid after the 20th week of gestation (WG), when fetal TSH receptors become responsive to TSH and TSAbs. On the other hand, transplacental passage of antithyroid drugs (ATD), which influence fetal thyroid much more than the maternal gland, can cause fetal hypothyroidism.

The progress in prenatal ultrasonography (US) enables early diagnosis of fetal thyroid dysfunction without performing invasive procedures such as fetal blood sampling. According to all the current guidelines [1 $\underline{-}-\underline{4}]$, fetal US monitoring should be performed after the 18th-22nd WG in case of either ATD therapy or maternal Graves' disease with elevated TSH receptor antibodies (TRAb), irrespective of maternal thyroid function.

The US symptoms of fetal hyperthyroidism include goiter, tachycardia (over 160 beats per minute registered for over 10 minutes), cardiomegaly, hydrops, accelerated bone maturation (presence of femoral epiphysis ossification centre before the 31st WG) and intrauterine growth restriction (IUGR). Fetal hypothyroidism can manifest with goiter, bradycardia (below 120 beats per minute), delayed bone maturation (absence of femoral epiphysis ossification centre after the 33rd WG) and IUGR.

Fetal goiter presents on US as an anterior neck mass which is solid, homogenous and maintains a characteristic lobular shape. A large goiter can cause head hyperextension and precludes vaginal delivery. Compression of the esophagus and trachea can lead to polyhydramnion and airway comprise at birth. So that early diagnosis of fetal goiter is essential and relies upon comparing thyroid size with reference values [므묘. As the presence of goiter accompanies both fetal hyper- and hypothyroidism the evaluation of blood flow by the Doppler technique may be helpful in discriminating these two abnormalities. An increased central blood flow throughout thyroid gland is indicative of fetal hyperthyroidism. In fetal hypothyroidism various patterns of thyroid vascularization are observed but an increased peripheral blood flow is the most characteristic feature.

According to some observations fetal goiter is demonstrative of fetal thyroid dysfunction with sensitivity $92 \%$, specificity 100\%, PPV 100\% and NPV 98\% [9]. On the other hand, abnormalities in fetal bone maturation which can be registered on US at the late stage of pregnancy, between 31 and 33 weeks of gestation, occurred in only $36 \%$ of cases when fetal thyroid dysfunction. Abnormal fetal heart rate appeared to be even more uncommon $(14 \%)$ and is a late sign of fetal hypo- or hyperthyroidism $[\underline{9}, \underline{10}]$.

Despite the great value of US, it must be emphasized that in the final assessment of the fetal thyroid status, serum concentrations of maternal thyroid hormones and anti-TSH receptor antibodies and the doses of maternal ATDs must be taken into account.

The author's own experience $[\underline{11}, \underline{12}]$ based on the observation of 42 cases of pregnant women with Graves' disease and US evaluation of the fetus indicates that:

- Fetal thyroid dysfunction occurs much more often than has been commonly reported: $21 \%$ vs. $1-5 \%$ [르, $\underline{13}]$.

- Fetal goiter is the most sensitive US sign of fetal thyroid dysfunction.

- Fetal thyroid gland affected by transplacental passage of maternal TSAbs can demonstrate the same characteristic

US features of Graves' disease as in adults: enlargement, hypoechogenicity and hypervascularisation.

\section{References}

1. Abalovich M, Amino N, Barbour LA, Cobin RH, De Groot LJ, Glinoer D, et al.: Management of thyroid dysfunction during pregnancy and postpartum: an Endocrine Society clinical practice guideline. $J$ Clin Endocrinol Metab 2007,92(8 Suppl):S1-S47.

2. The American Thyroid Association Taskforce on Thyroid Disease During Pregnancy and Postpartum, Stagnaro-Green A, Abalovich M, Alexander E, Azizi F, Mestman J, et al.: Guidelines of the American thyroid association for the diagnosis and management of thyroid disease during pregnancy and postpartum. Thyroid 
3. Hubalewska-Dydejczyk A, Lewiński A, Milewicz A, Radowicki S, Poreba R, Karbownik-Lewińska M, et al.: Management of thyroid diseases during pregnancy. Endokrynol Pol 2011,62(4):362-381.

4. De Groot L, Abalovich M, Alexander EK, Amino N, Barbour L, Cobin RH, et al.: Management of thyroid dysfunction during pregnancy and postpartum: an Endocrine Society clinical practice guideline. $J$ Clin Endocrinol Metab 2012,97(8):2543-2565. 10.1210/jc.2011-2803

5. Ranzini AC, Ananth CV, Smulian JC, Kung M, Limbachia A, Vintzileos AM: Ultrasonography of the fetal thyroid. Nomograms based on biparietal diameter and gestational age. J Ultrasound Med 2001,20(6):613-617.

6. Radaelli T, Cetin I, Zamperini P, Ferrazzi E, Pardi G: Intrauterine growth of normal thyroid. Gynecol Endocrinol 2002,16(6):427-430. 10.1080/gye.16.6.427.430

7. Bernardes LS, Ruano R, Sapienza AD, Maganha CA, Zugaib M: Nomograms of fetal thyroid measurements estimated by 2-dimensional sonography. J Clin Ultrasound 2008,36(4):193-199. 10.1002/jcu.20434

8. Gietka-Czernel M, Dębska M, Kretowicz P, Debski R, Zgliczyński W: Fetal thyroid in twodimensional ultrasonography: nomograms according to gestational age and biparietal diameter. Europ J Obstet Ginecol Rep Biol 2012,162(2):131-138. 10.1016/j.ejogrb.2012.02.013

9. Luton D, Le Gac I, Vuillard E, et al.: Management of Graves' disease during pregnancy: the key role of fetal thyroid monitoring. J Clin Endocrinol Metab 2005,90(11):6093-6098. 10.1210/jc.2004-2555

10. Nachum Z, Rakower Y, Weiner E, Shalev E: Graves' disease in pregnancy: prospective evaluation of a selective invasive treatment protocol. Am J Obstet Gynecol 2003,189(1):159-165. 10.1067/mob.2003.321

11. Gietka-Czernel M, Dębska M, Kretowicz P, Zgliczyński W, Ołtarzewski M: Hyperthyroidism during pregnancy - the role of measuring maternal TSH receptor antibodies and foetal ultrasound monitoring. Endokrynol Pol 2014,65(4):259-268. 10.5603/EP.2014.0035

12. Gietka-Czernel M, Dębska M, Kretowicz P, Jastrzębska H, Zgliczyński W: Increased size and vascularisation, plus decreased echogenicity, of foetal thyroid in two-dimensional ultrasonography caused by maternal Graves' disease. Endokrynol Pol 2014,65(1):64-68. 10.5603/EP.2014.0009

13. Krassas GE, Poppe K, Glinoer D: Thyroid function and human reproductive health. Endocr Rev 2010,31(5):702-755. 10.1210/er.2009-0041 